\title{
PHYSICAL AND CHEMICAL CHARACTERISTICS AND STRUCTURE OF CARMINOMYCIN, A NEW ANTITUMOR ANTIBIOTIC
}

\author{
M. G. Brazhnikova, V. B. Zbarsky, V. I. Ponomarenko \\ and N.P. Potapova \\ Institute of New Antibiotics, Academy of Medical Sciences, \\ Moscow, USSR
}

(Received for publication October 22, 1973)

\begin{abstract}
In the course of our screening program we have isolated from the culture fo Actinomadura carminata carminomycin, a new anthracycline antibiotic which possessed strong antitumor activity in animal experiments. It is produced as a mixture of several active components: the more interesting ones are components 1,2 and 3 . Components 2 and 3 can be transformed by means of mild hydrolysis into carminomycin 1 , which is obtained as a red crystalline hydrochloride $\mathrm{C}_{26} \mathrm{H}_{27} \mathrm{O}_{10} \mathrm{~N} \cdot \mathrm{HCl}$. The ultraviolet and visible spectra resemble that of daunomycin but are different.

Carminomycin 1 on hydrolysis with $0.1 \mathrm{~N}$ hydrochloric acid, yields daunosamine and an aglycone, carminomycinone. The structure of aglycone and carminomycin 1 was determined by physical-chemical methods.
\end{abstract}

Carminomycin was isolated from the mycelium of Actinomadura carminata ${ }^{1)}$ in the form of a complex preparation, which contains seven colored components, five of which are biologically $\operatorname{active}^{2,3)}$. Carminomycins 2 and 3 are produced preferentially. The other components of the carminomycin complex are present in negligible amounts. By extraction and chromatography on silicic acid from chloroform-benzene-methanol $(7: 3: 3)$, three of the more active components were separated from the less active ones. Fig. 1 shows the separation of the complex preparation by means of thin-layer chromatography on silica gel G. The complex preparations contain $50 \%$ of carminomycin 2 and $30 \%$ of carminomycin 3. All three active components were obtained in the form of free bases. Carminomycin 1, which presents the greatest interest

Fig. 1. Chromatogram of the summary preparation of carminomycin in the thin-layer of silica gel $\mathrm{G}$ (chloroform-methanol-benzene 7 : $3: 3)$.

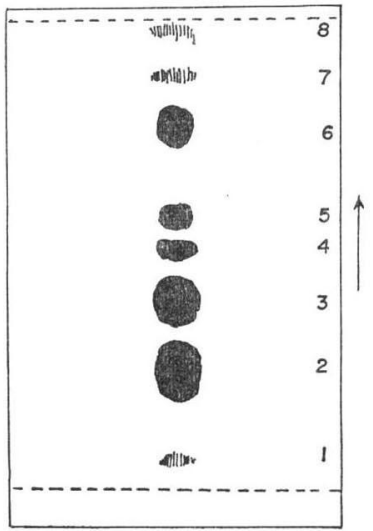

from the chemotherapeutic point of view, was also obtained in the form of a hydrochloride crystallized from a mixture of ethanol and benzene. The crystalline salt is soluble in water and methanol, and insoluble in other organic solvents. The biological assays determined by the agar-diffusion method with Bacillus mycoides as test organism, give for carminomycins 1, 2 and 3, respectively, 1,000 u/mg, $580 \mathrm{u} / \mathrm{mg}$ and $730 \mathrm{u} / \mathrm{mg}$. In Table 1 are given certain physico-chemical properties of the carminomycins. As can be seen, carminomycin 3 is more lipophylic than carminomycins 1 and 2. This follows from comparison of the coefficients of distribution in the system chlo- 
Table 1. Comparison of physico-chemical properties of carminomycins 1, 2 and 3 .

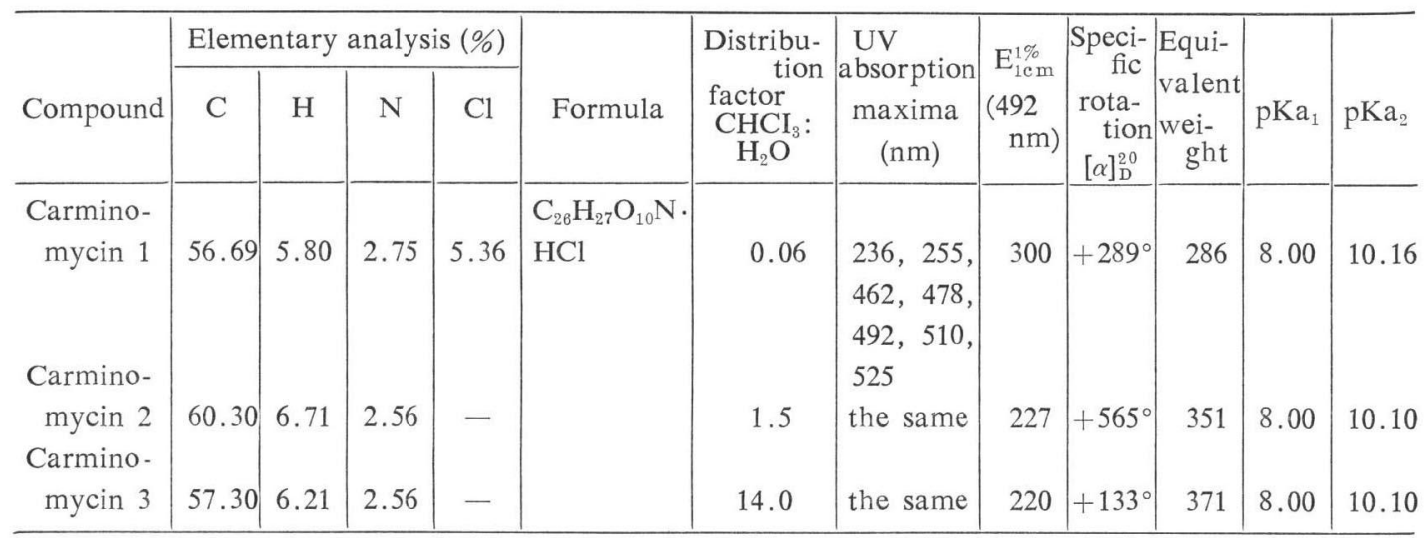

Fig. 2. Absorption spectra of carminomycin and daunomycin $(\mathrm{EtOH})$.

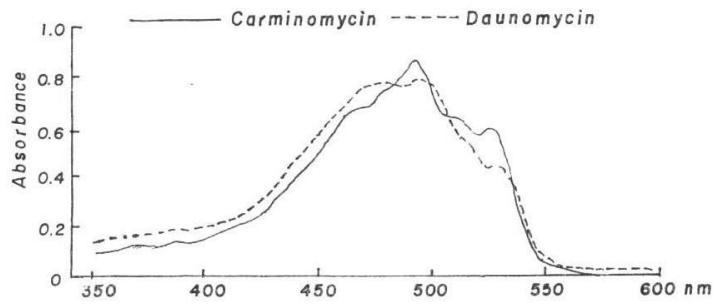

Fig. 3. IR-spectras of carminomycin (a) and daunomycin (b) (KBr).

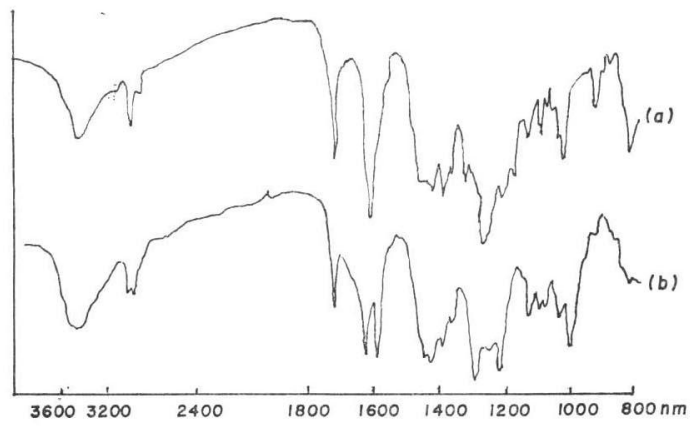

roform-water at $\mathrm{pH} 4.3$.

Carminomycins possess the ultraviolet and visible spectra, typical of anthracyclines. These spectra are closest to the spectra of daunomycin, though different (Fig. 2). Specific absorption at $492 \mathrm{~nm}$ is practically the same for carminomycins 2 and 3 , but is 80 units less than the specific absorption of carminomycin 1 .

IR spectra of carminomycin 1 and daunomycin, shown in Fig. 3 also demonstrate the differences of these two antibiotics. Carminomycins 1, 2 and 3 have different specific optical rotation. The equivalent weight by potentiometric titration is less for carminomycin 1 than for carminomycins 2 and 3 . The same conclusion can be made from differences in specific absorption of carminomycins. The $\mathrm{pK}_{\mathrm{a}}$ figures show that amino and phenolic groups are present in carminomycins.

Carminomycins 2 and 3 can be transformed into carminomycin 1 by means of mild hydrolysis with the liberation of carbohydrate fragments, similar to the conversion of rubomycin $\mathbf{B}$ into rubomycin $\mathbf{C}^{7,8)}$.

Carminomycins 4,5 and 6 in the complex preparation in small quantities have been isolated by chromatography on silicic acid. Carminomycin 4 is a brick-red amorphous substance, easily soluble in most of organic solvents. It is biologically active $(450 \mathrm{u} / \mathrm{mg})$. It contains $2.4 \%$ nitrogen and is not changed under mild hydrolysis.

Carminomycin 5 is a dark-red amorphous substance, easily soluble in organic solvent assays $350 \mathrm{u} / \mathrm{mg}$, contains $2.17 \%$ nitrogen and does not change under mild hydrolysis.

Carminomycin 6 is a crystalline substance without nitrogen. It is also formed during 
Table 2. Comparison of physico-chemical properties of carminomycinone, daunomycinone and their derivatives.

\begin{tabular}{|c|c|c|c|c|c|c|}
\hline Compound & Formula & $\begin{array}{c}\mathrm{CH}_{3} \mathrm{O}- \\
(\%)\end{array}$ & $\begin{array}{c}\text { Melting } \\
\text { point }\left({ }^{\circ} \mathrm{C}\right)\end{array}$ & Specific rotation $[\alpha]_{\mathrm{D}}^{20}$ & $\begin{array}{c}\text { UV } \\
\text { absorp- } \\
\text { tion (nm) } \\
(\mathrm{EtOH}) \\
\end{array}$ & $\mathrm{E}_{1 \mathrm{~cm}}^{1 \%}$ \\
\hline Carminomycinone & $\mathrm{C}_{20} \mathrm{H}_{16} \mathrm{O}_{8}$ & none & 224 & $+272^{\circ}(c \quad 0.1$, dioxane $)$ & 492 & 400 \\
\hline Daunomycinone & $\mathrm{C}_{21} \mathrm{H}_{18} \mathrm{O}_{8}$ & 7.53 & 214 & $+193^{\circ}$ (c 0.1, dioxane $)$ & 495 & 310 \\
\hline $\begin{array}{l}\text { Carminomycinone } \\
\text { acetate }\end{array}$ & $\mathrm{C}_{30} \mathrm{H}_{26} \mathrm{O}_{13}$ & none & 190 & $+40^{\circ}$ ( c 0.11, chloroform $)$ & 346 & 244 \\
\hline Daunomycinone acetate & $\mathrm{C}_{29} \mathrm{H}_{26} \mathrm{O}_{13}$ & 5.43 & 225 & $-95.5^{\circ}(\mathrm{c} \quad 0.11$, chloroform $)$ & 379 & 116 \\
\hline $\begin{array}{l}\text { Carminomycinone } \\
\text { tetramethyl }\end{array}$ & $\mathrm{C}_{24} \mathrm{H}_{24} \mathrm{O}_{8}$ & 28.17 & 188 & $+266^{\circ}(c \quad 0.1$, dioxane $)$ & 376 & 197 \\
\hline $\begin{array}{l}\text { Daunomycinone } \\
\text { trimethyl }\end{array}$ & $\mathrm{C}_{24} \mathrm{H}_{24} \mathrm{O}_{8}$ & 28.17 & 193 & $+181^{\circ}($ c 0.1 , dioxane $)$ & 376 & 197 \\
\hline
\end{tabular}

hydrolysis of carminomycins 1,2, 3, 4 and 5 and therefore represents the aglycone of these antibiotics.

When carminomycin 1 is hydrolyzed $(0.1$ $\mathrm{N}$ hydrochloric acid, $100^{\circ} \mathrm{C}, 30$ minutes), it yields a red aglycone and aminosugar (carminosamine) which has positive reaction with ninhydrin. The aminosugar has been isolated from hydrolyzates of carminomycins 1,2 and 3 by chromatography on Dowex $50 \times 12\left(\mathrm{H}^{+}\right)$ with $0.5 \mathrm{~N}$ ammonia. The specific rotation of the basic aminosugar $[\alpha]_{\mathrm{D}}^{20} 54.6^{\circ}$ (c) 0.1 , water) and chromatography on paper and Silufol plate revealed that carminosamine is identical with daunosamine. The N, O-acetates of the methylglycosides of carminosamine and daunosamine gave identical n. m. r. spectra.

These data show that carminomycin 1 differs from other anthracycline antibiotics in the aglycone.

We prepared crystalline carminomycinone, its acetate and methyl ether and similar derivatives of daunomycinone ${ }^{4,5,6)}$ for comparison. Table 2 shows the physico-chemical properties of carminomycinone and its derivatives. Carminomycinone has no methoxyl groups whereas daunomycinone contains $7.53 \%$ methoxyl, which represents one group per mole of aglycone. The elementary formula of carminomycinone differs from that of daunomycinone by $\mathrm{CH}_{2}$ and they have the same oxygen content. This indicates that carminomycinone contains a hydroxyl instead of methoxyl.

Fig. 4 shows the IR-spectra of the aglycones. In both compounds the band at $1715 \mathrm{~cm}^{-1}$ $\left(\nu^{\mathrm{C}=0}\right)$ is assigned to a $\mathrm{COCH}_{3}$ group in the hydroaromatic ring. The band at $1625 \mathrm{~cm}^{-1}$ in daunomycinone can be assigned to the carbonyl groups of the anthraquinone, the band at $1580 \mathrm{~cm}^{-1}$ to the aromatic double bond system. The substitution of $-\mathrm{OCH}_{3}$ group by hydroxyl is accompanied by a shift of $1625 \mathrm{~cm}^{-1}$ band towards lower frequencies $\left(1610 \mathrm{~cm}^{-1}\right)$ hydrogen bonding. This gives superimposition of $\nu^{\mathrm{C}=0}$ and $\nu^{\mathrm{C}=\mathrm{C}}$ vibrations in one band at $1610 \mathrm{~cm}^{-1}$.

The difference between carminomycinone and daunomycinone is clear from the NMR-spectra 
Fig. 5. NMR-spectra of acetates of carminomycinone (a) and daunomycinone (b) $(60 \mathrm{MHz}$, $\left.\mathrm{CDCl}_{3}\right)$.

(b)

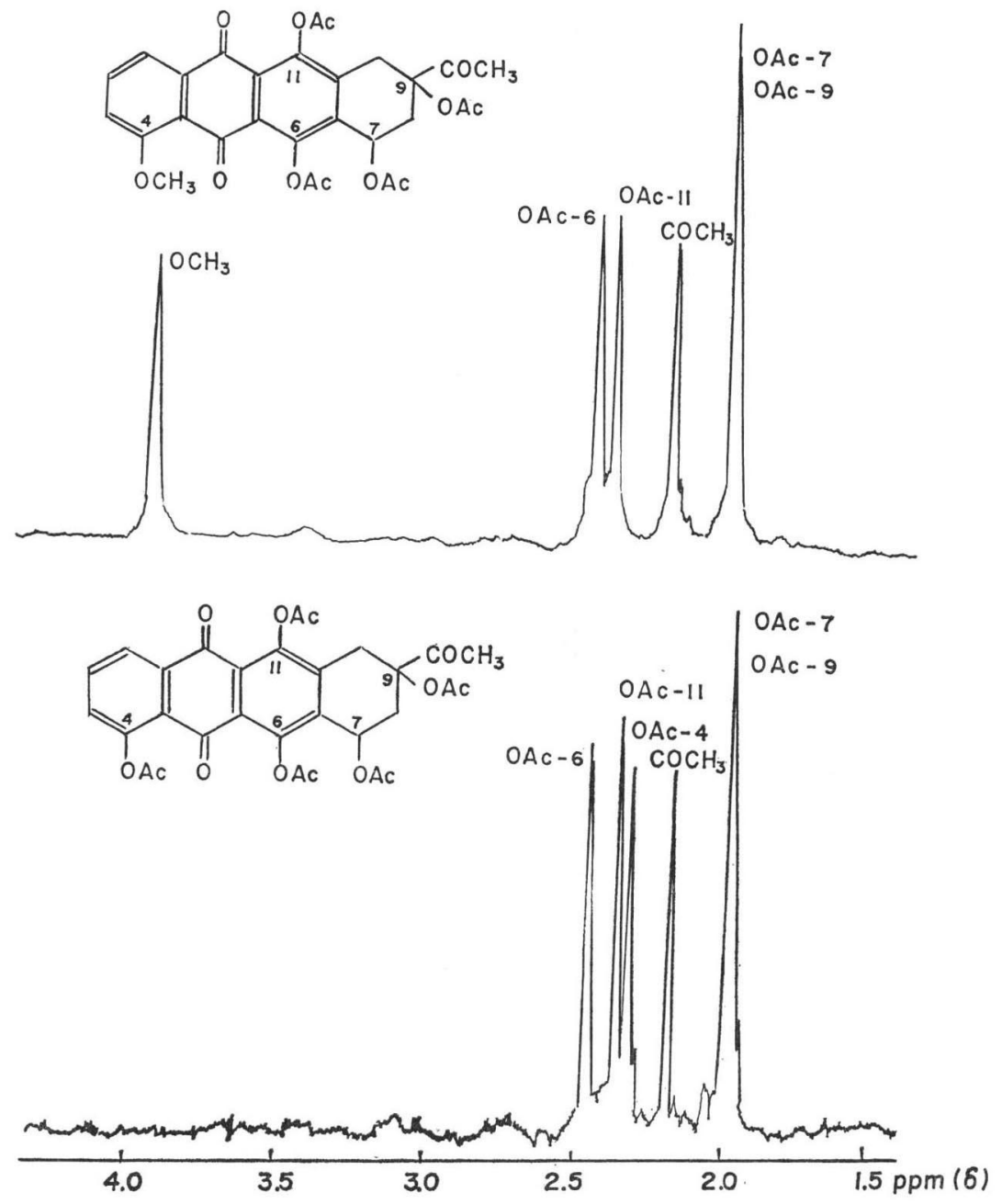

of their acetates. The spectrum of carminomycinone acetate (Fig. 5) has three three-proton singlets $(\delta 2.33,2.38,2.45 \mathrm{ppm})$ which belong to acetoxyls attached to $\mathrm{C}_{4}, \mathrm{C}_{11}$ and $\mathrm{C}_{6}$ respectively and one six-proton singlet. $(\delta 1.85 \mathrm{ppm})$ from the acetoxyls attached to $\mathrm{C}_{7}$ and $\mathrm{C}_{8}$. The spectrum of daunomycine acetate lacks the singlet at $\delta 2.33 \mathrm{ppm}$ and has a three proton singlet at $\delta 3.92 \mathrm{ppm}$, corresponding to methoxyl at $\mathrm{C}_{4}$. Thus carminomycinone differs from daunomycinone by substitution at $\mathrm{C}_{4}$ with hydroxyl rather than methoxyl.

The methyl ethers of both aglycones contain the same percentage of methoxyl groups and have the same molecular formulas. The NMR-spectra of ethers (Fig. 6) have two three-proton singlets $\left(\delta 3.89\right.$ and $3.56 \mathrm{ppm}$ ), assigned to the methoxyls attached to $\mathrm{C}_{4}$ and $\mathrm{C}_{7}$ and one sixproton singlet $(\delta 4.00 \mathrm{ppm})$, from the methoxyls at $\mathrm{C}_{6}$ and $\mathrm{C}_{11}$, confirming the above structural assignment.

The attachment of the sugar in the antibiotic was proven by hydrogenolysis of carminomycin $\left(5 \% \quad \mathrm{Pd} / \mathrm{BaSO}_{4}\right)$ with elimination of the hydroxyl and the attached sugar ${ }^{6}$. Hydro- 
Fig. 6. NMR-spectrum of methyl ether of carminomycinone $\left(100 \mathrm{MHz}, \mathrm{CDCl}_{3}\right)$.

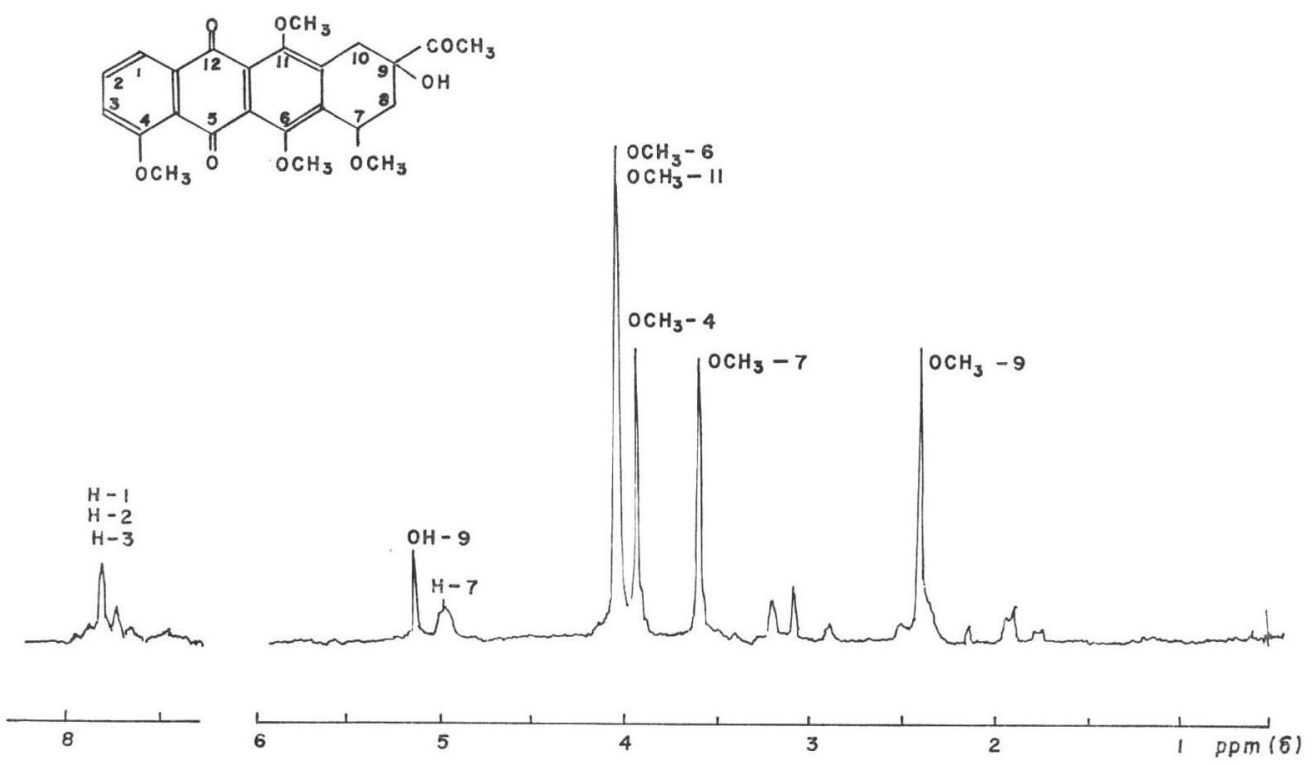

Fig. 7. Diagram of splitting of carminomycinone in conditions of mass-spectrometry.

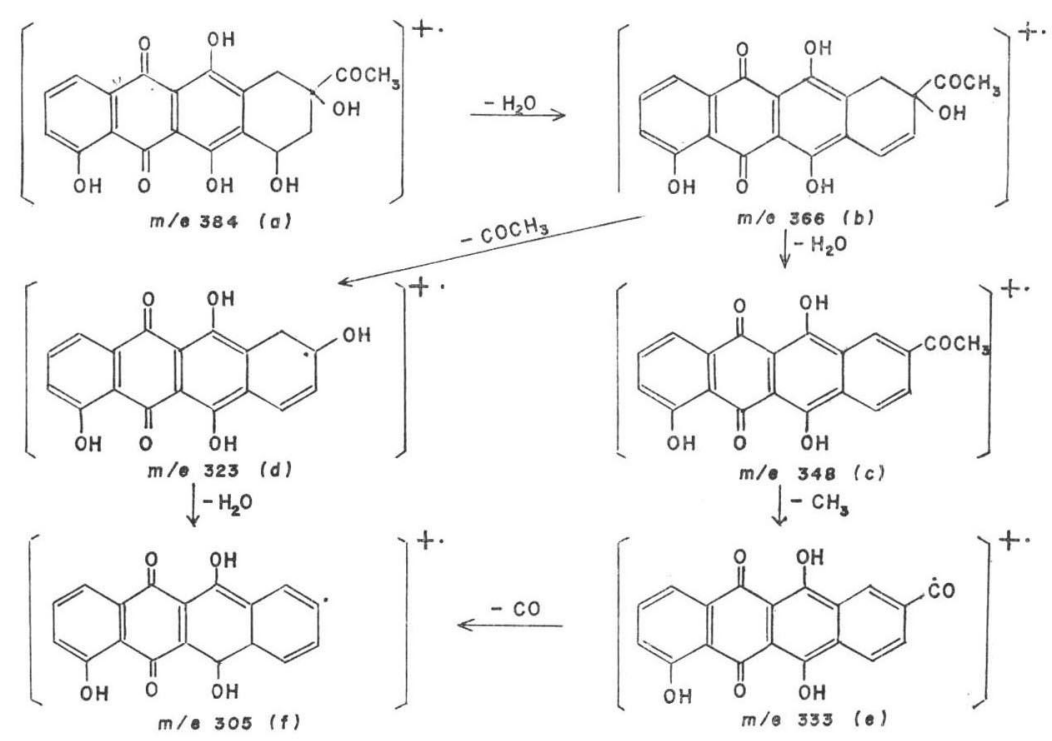

genation of the aglycone under the same conditions gave a product identical with the product from hydrogenolysis of the antibiotic. The NMR-spectrum of the acetate of the reduced aglycone showed the absence of acetyl at $\mathrm{C}_{7}$ that identifying the hydroxyl involved in the glycosidic bond.

The difference in the melting points of the methyl ethers of carminomycinone and daunomycinone and in the specific rotation of the aglycones and their derivatives implies that the stereochemical properties of aglycones may be different. The stereochemistry of carminomycinone is being investigated at present and will be reported in a separate paper. 
Fig. 8. Structural formula of carminomycin 1.<smiles>CC(=O)C1(O)Cc2c(O)c3c(c(O)c2C2CC(C)OC(CC2N)O3)C(=O)c2c(O)cccc2C1=O</smiles>

Fig. 7 shows a possible scheme for massspectral fragmentation of carminomycinone. The molecular ion $m / e 384^{+}$(a) in consecutive order loses two molecules of water from elimination of hydroxyls at $\mathrm{C}_{7}$ and $\mathrm{C}_{\vartheta}$ with formation of the fragments $m / e 366^{+}$(b) and $348^{+}(c)^{9}$. Other assignments can be made for ions at $m / e 323^{+}\left(\mathrm{b}-\mathrm{COCH}_{3}(\mathrm{~d})\right), 333^{+}$ $\left(\mathrm{c}-\mathrm{CH}_{3}(\mathrm{e})\right)$ and $305\left(\mathrm{~d}-\mathrm{H}_{2} \mathrm{O}(\mathrm{f})\right)$, and are confirmed by the corresponding metastable

peaks. Therefore, the massspectrum supports the structure of carminomycinone (Fig. 7a), as a 1, 4, 5-trioxyanthraquinone.

Since glycosidic bond is at $\mathrm{C}_{7}$ and carbohydrate fragment is represented by daunosamine, the structural formula of carminomycin 1 may be proposed as shown in Fig. 8 .

The study of crystalline carminomycin 1 in animal experiments showed that cancer of praestomach in mice, strain OG-5, is suppressed by $80 \%$ with three intravenous injections of half the $\mathrm{LD}_{50}$. The bronchogenous lung cancer, strain $\mathrm{RL}$, in experiments on mice, with similar dosages is $95 \%$ suppressed by carminomycin. Especially interesting were the results obtained in treating the ascitic form of lymphatic leukemia in mice, strain 1210 . In this case the effectiveness of carminomycin 1 is twice as effective as the synthetic antitumor preparation methothrexate. Some of the mice treated with carminomycin 1 survived whereas all mice treated with methothrexate or daunomycin died. In contrast to other antibiotics of this group, carminomycin 1 is very well absorbed from gastroentestinal tract when given orally ${ }^{3)}$.

\section{References}

1) Gauze, G. F.; M. A. Sveshikova, R.S. Ukholina, G. V. Gavrilina, V. A. Filicheva \& E. G. GladKIKH: Production of antitumor antibiotic carminomycin by Actinomadura carminata sp. nov. Antibiotiki 18: 675 678, 1973

2) Brazhnikova, M. G.; V.B. Zbarsky, M. K. Kudinova, L. I. Muravieva, V. I. Ponomarenko \& N.P. Potapova: Carminomycin, a new antibiotic anthracycline. Antibiotiki 18: 678 681, 1973

3) Shorin, V.A.; V.S. Bazhanov, L. A. Averbuch, G. N. Lepeshikina \& A. M. Grinshtein: Antitumor activity of a new antibiotic carminomycin. Antibiotiki 18: 681 687, 1973

4) Arcamone, F.; G. Franceschi, P. Oressi, G. Cassinelli, W. Barbieri \& R. Mondelli: The structure of daunomycinone. J. Am. Chem. Soc. 86:5334 5335, 1964

5) Arcamone, F.; G. Franceschi, P. Oressi, S. Penco \& R. Mondelli: The structure of daunomycinone. Tetrahedron Letters 1968-30: 3349 3352, 1968

6) Iwamoto, R.N.; P. Lim \& N.S. Bhassa: The structure of daunomycin. Tetrahedron Letters 196836: $3891 \sim 3894,1968$

7) Brazhnikova, M. G.; N. V. Konstantinova, A.S. Mezentsev \& V.A. Pomazkova: Studies on chemical properties of rubomycin B. Antibiotiki 13: 781 785, 1968

8) Fedorova, G. V.; M. G. Brazhnikova, A.S. Mezentsev \& I. Kshapinsky: Studies on carbohydrate composition of rubomycin B. Antibiotiki 15: 403 406, 1970 